\title{
Preprocessing and Hybrid
} Biochemical/Thermochemical Conversion of Short Rotation Woody
Coppice for Biofuels

\author{
C. Luke Williams*, Rachel M. Emerson, Sergio Hernandez, Jordan L. Klinger, \\ Eric P. Fillerup and Brad J. Thomas
}

Idaho National Laboratory, Idaho Falls, ID, United States

Preprocessing with air classification, followed by a hybrid biochemical/thermochemical conversion scheme, was utilized to improve the quality of short rotation woody coppice (SRWC) for biofuels production. Air classification improved sugar release during enzymatic hydrolysis by $6-12 \%$ for poplar and willow coppice respectively. Total theoretical sugar release for these hardwood coppices was $\sim 70 \%$, which suggests

OPEN ACCESS

Edited by:

Timothy G. Rials,

University of Tennessee, Knoxville,

United States

Reviewed by:

Selhan Karagoz,

Karabük University, Turkey

Abu Yousuf,

Shahjalal University of Science and

Technology, Bangladesh

*Correspondence:

C. Luke Williams

luke.williams@inl.gov

Specialty section

This article was submitted to

Bioenergy and Biofuels,

a section of the journal

Frontiers in Energy Research

Received: 15 March 2018

Accepted: 09 July 2018

Published: 30 July 2018

Citation:

Williams CL, Emerson RM,

Hernandez S, Klinger JL, Fillerup EP and Thomas BJ (2018) Preprocessing

and Hybrid

Biochemical/Thermochemical Conversion of Short Rotation Woody

Coppice for Biofuels.

Front. Energy Res. 6:74.

doi: 10.3389/fenrg.2018.00074 that they could be utilized for biochemical conversion. Improved sugar yields after air classification were tied to compositional changes of reduced ash and extractives which can neutralize dilute acid pretreatment and inhibit fermentation. However, air classification was shown to have little to no effect on pyrolytic thermochemical conversion as it removed material without returning a significant improvement in liquid yield. It was also shown that pyrolysis of biochemical conversion lignin rich residue gives liquid yields comparable to whole tree (without any fractionation) pyrolysis, with a higher quality oil that has $\sim 60 \%$ reduced total acid number. Using this combined biochemical/thermochemical conversion strategy can improve yields of fermentable sugars and pyrolysis liquid above $80 \%$, instead of the $60 \%$ yield of sugars or bio-oil when using a single conversion strategy. Overall, it has been shown that preprocessing and hybrid conversion pathways are a viable strategy for maximizing biorefinery viability.

Keywords: preprocessing, hybrid, biochemical, thermochemical, conversion, coppice, biofuels

\section{INTRODUCTION}

In an effort to shift the world's energy paradigm away from finite petroleum resources there has been an increased focus on renewable energy, fuels, and chemicals. Biomass fills a unique role in this paradigm because, as the only carbon based renewable energy source, it is uniquely suited to the production of liquid fuels and chemicals. Other renewable energy sources, such as solar, wind, and hydro are effective for electricity production but are not amenable to the direct production of liquid and solid products. To produce these renewable fuels and chemicals it will be necessary to utilize the billion tons of residual biomass available in the United States (US Department of Energy, 2011). Currently, there exists two distinct pathways for biomass conversion; biochemical and thermochemical, and the choice of which one to use comes down to the inherent properties of the available biomass (Williams et al., 2017). This work makes an effort to bridge the gap between biochemical and thermochemical processes and identify strategies to effectively utilize short rotation woody coppice 
(SRWC), represented by hybrid poplar and shrub willow, for a hybrid (combined biochemical and thermochemical) conversion scheme.

Coppicing involves cutting the stand down just above the ground after 1 year to promote rapid growth of smaller stems that can be harvested every 3 years over a 20 year period (Volk et al., 2006). Coppicing also allows for high energy yields per acer (Njakou Djomo et al., 2015), maximized growth potential through active root systems (Mitchell, 1992; Al Afas et al., 2008), and an increased harvesting frequency as compared to short rotation forestry (Kauter et al., 2003). Coppice crops have recently been considered for both biochemical (Dou et al., 2017b) and thermochemical conversion (Dou et al., 2017a). Advantageously, these resources have compositional properties between traditional lignocellulosic (pine) and herbaceous (corn stover) feedstocks (Williams et al., 2016) which could make them well suited to a hybrid biochemical/thermochemical conversion. While clean chips of poplar and willow have been identified to have favorable carbohydrate contents for biochemical conversion processes (Volk et al., 2006; Sannigrahi et al., 2010), excessive leaf and bark material can negatively impact conversion (Wyman et al., 2009; Dou et al., 2017b). Additionally, higher lignin content of leaves and bark is a compositional aspect that should be considered, high lignin lends itself to thermochemical conversion processes; conversely, the higher ash contents in bark and leaves may cause problems with high temperature conversion (Carpenter et al., 2017; Zinchik et al., 2018).

One key benefit of a hybrid conversion pathway is the ability to more easily produce a combination of platform chemical precursors and fuel, derived from biomass based sugars and lignin rich residue respectively (De Wild et al., 2014; Ragauskas et al., 2014). Biomass derived sugars can either be fermented to ethanol and blended with fuel (the traditional use) or transformed into building blocks for high-value materials like p-xylene (Williams et al., 2012; Chang et al., 2014), toluene (Green et al., 2016), and butanol (Nigam and Singh, 2011). The lignin rich hydrolysis reside, on the other hand, is typically combusted for biorefinery power generation or used as a local animal feed supplement. Another option for this lignin rich residue is conversion into a bio-oil that could be further upgraded liquid transportation fuel. This paper will evaluate the effectiveness of converting hybrid poplar and shrub willow to sugars (through enzymatic hydrolysis) and bio-oil (through fast pyrolysis). In addition, SRWC anatomical fractions (separated by hand and using air classification as a preprocessing step) were passed through each conversion process to understand how anatomical fractionation alters conversion yields. Finally, a hybrid pathway, where the lignin rich residue from biochemical conversion was utilized for bio-oil production through fast pyrolysis, was also explored. Utilizing lignin rich residues from pulp and paper processes has only recently been demonstrated at scale (De Wild et al., 2014). To the best of the authors' knowledge, no studies have focused on the fast pyrolysis of lignin rich residue from a biochemical conversion process; in particular, not for emerging energy crops like poplar and willow.

\section{MATERIALS AND METHODS}

\section{Materials Sourcing}

Hybrid poplar ( $P$. deltoides $\times P$. nigra.), from a 3 year coppice with 5 year old roots, was harvested July 14, 2017 from Kootenai County, Idaho using a New Holland FR 9080 forage harvester with a FB130 coppice header producing chip dimensions around $1^{\prime \prime} \times 2^{\prime \prime} \times 12^{\prime \prime}$. Shrub willow was harvested September 5, 2017 from Jefferson County, New York from Celtic Energy Farms plots using the same harvesting method as the poplar. Once received, approximately $200 \mathrm{~kg}$ of each of material was divided into representative subsamples using a custom rotary splitter. Each subsample consisted of $2.5-3.5 \mathrm{~kg}$ of wet material for air classification, anatomical fractionation, characterization, and conversion. Moisture content for air classification was $45.4 \%$ for hybrid poplar and $52.6 \%$ for shrub willow. Processed samples were dried at $105^{\circ} \mathrm{C}$ for $24-30 \mathrm{~h}$ using a high performance horizontal air flow drying oven (SHEL LAB, model no. FX28-2, Cornelius, OR). Samples not processed within a week were stored frozen at $-20^{\circ} \mathrm{C}$.

\section{Biomass Fractionation}

Air classification (AC) was performed on wet chips using a 2x Air Cleaner equipped with an Iso-flow dewatering infeed shaker (Key Technologies, Walla Walla, WA). Air classification separates the samples into two fractions (light and heavy) by passing material over a screen covered fan. The lighter fraction (primarily low quality fines, leaves, and bark) is blown upward and pneumatically conveyed into a separate container than the heavy fraction, which passes over the fan. Several air velocities were tried until a flow rate was found that removed the majority of the leaves and bark but retained the majority of the chips $(\sim 4.7$ $\mathrm{m} / \mathrm{s})$.

Additionally, anatomical fractions were separated by hand to create a clean chip fraction (white chips without any bark), and an unclean mix (the fraction containing leaves, twigs, branches, free bark, chips with bark, and fines). This separation of clean chips and an unclean mix was chosen to represent the best possible fractionation scheme. Both air classification and anatomical fractionation was done in triplicate for all samples and the results of the different fractionation methods can be seen in Table 1. It should also be noted that this table also contains the results of the residual lignin rich residue that is left over after biochemical pretreatment.

TABLE 1 | Mass fractions on a dry basis for hybrid poplar and shrub willow fractionation methods.

\begin{tabular}{lcccc}
\hline & $\begin{array}{c}\text { Heavy-Air } \\
\text { classified }\end{array}$ & $\begin{array}{c}\text { Clean } \\
\text { chips }\end{array}$ & $\begin{array}{c}\text { Unclean } \\
\text { mix }\end{array}$ & $\begin{array}{c}\text { Biochem } \\
\text { residue }\end{array}$ \\
\hline Hybrid poplar & $88.36(0.21)$ & $64.63(2.22)$ & $35.37(4.07)$ & $42.01(\mathrm{~N} / \mathrm{A})$ \\
Shrub willow & $87.69(0.64)$ & $50.69(1.90)$ & $49.31(4.26)$ & $44.6(\mathrm{~N} / \mathrm{A})$ \\
\hline
\end{tabular}

Presented as the mean and (standard deviation). It should be noted that the light air classified sample is 100 minus the heavy fraction and the biochemical residue is the solids fraction left over after pretreatment and enzymatic hydrolysis. 


\section{Sample Preparation}

Samples were ground to pass a $2.0 \mathrm{~mm}$ screen using a Thomas Model 4 Wiley knife mill (Thomas Scientific, model no. 3375-E55, Swedesboro, NJ) based on ASTM E1757-01 for compositional analysis and biochemical conversion. Samples were further ground to pass a $200 \mu \mathrm{m}$ sieve (Retsch ZM 200) for thermochemical conversion analyses. To prepare samples for pyrolysis approximately $1 \mathrm{~g}$ of material was compressed into a $16 \mathrm{~mm}$ square custom die with rounded corners at approximately $20,000 \mathrm{lb}_{\mathrm{f}}$ for $1 \mathrm{~min}$ using a Carver press (3853-0C, Carver Inc.).

\section{Chemical Characterization}

Compositional analysis was performed following the standard Laboratory Analytical Procedures for Compositional Analysis developed at NREL (Sluiter et al., 2010). The details of the procedure are summarized below. Extractives were removed using an accelerated solvent extractor (ASE) 350 (ThermoFisher, Scientific, Waltham, MA) three times with both water and

TABLE 2 | Compositional analysis of hybrid poplar, shrub willow, and their air classified fractions.

\begin{tabular}{|c|c|c|c|c|c|c|}
\hline & \multicolumn{3}{|c|}{ Hybrid poplar } & \multicolumn{3}{|c|}{ Shrub willow } \\
\hline & $\begin{array}{c}\text { Whole } \\
\text { tree }\end{array}$ & $\begin{array}{c}\text { Heavy } \\
\text { AC }\end{array}$ & $\begin{array}{l}\text { Clean } \\
\text { chips }\end{array}$ & $\begin{array}{c}\text { Whole } \\
\text { tree }\end{array}$ & $\begin{array}{l}\text { Heavy } \\
\text { AC }\end{array}$ & $\begin{array}{l}\text { Clean } \\
\text { chips }\end{array}$ \\
\hline Whole ash & 2.22 & 1.65 & 0.47 & 3.22 & 2.53 & 0.74 \\
\hline Structural ash & 1.12 & 0.56 & 0.22 & 1.66 & 1.57 & 0.01 \\
\hline Extractable inorganics & 1.11 & 1.09 & 0.27 & 1.56 & 0.96 & 0.73 \\
\hline $\mathrm{H}_{2} \mathrm{O}$ extractives & 4.57 & 3.74 & 2.48 & 5.82 & 6.26 & 2.99 \\
\hline Total extractives & 6.38 & 5.40 & 3.88 & 9.29 & 9.53 & 5.00 \\
\hline Lignin & 26.90 & 27.28 & 27.13 & 25.49 & 25.73 & 25.46 \\
\hline Glucan & 37.89 & 40.14 & 42.68 & 35.81 & 37.47 & 41.35 \\
\hline Xylan & 13.83 & 14.76 & 15.67 & 12.99 & 13.43 & 15.66 \\
\hline Galactan & 1.51 & 1.63 & 1.34 & 1.87 & 1.78 & 1.31 \\
\hline Arabinan & 0.66 & 1.22 & 0.60 & 1.40 & 1.26 & 0.41 \\
\hline Mannan & 2.43 & 2.87 & 2.60 & 1.96 & 2.05 & 2.13 \\
\hline Total sugars & 56.32 & 60.62 & 62.89 & 54.03 & 55.99 & 60.86 \\
\hline Acetate & 4.21 & 5.17 & 5.18 & 3.95 & 4.26 & 4.98 \\
\hline Total & 94.91 & 98.85 & 99.30 & 94.42 & 96.93 & 96.32 \\
\hline
\end{tabular}

Whole tree material has undergone no separation step, the heavy AC fraction is air classified, and the clean chips were separated by hand. Values are given as a percent dry weight basis where the "total" value represents the final mass balance closure.

TABLE 3 | Pyrolysis yields for whole, hand fractionated, and air classified hybrid poplar for the mean and (standard deviation).

\begin{tabular}{lccccc}
\hline \multicolumn{5}{c}{ Hybrid poplar } \\
\cline { 2 - 6 } & $\begin{array}{c}\text { Whole } \\
\text { tree }\end{array}$ & $\begin{array}{c}\text { Clean } \\
\text { chips }\end{array}$ & $\begin{array}{c}\text { Unclean } \\
\text { mix }\end{array}$ & $\begin{array}{c}\text { Heavy } \\
\text { AC }\end{array}$ & $\begin{array}{c}\text { Light } \\
\text { AC }\end{array}$ \\
\hline Liquid & $59.81(0.87)$ & $65.28(0.94)$ & $50.84(3.39)$ & $60.56(0.67)$ & $48.86(1.29)$ \\
Char & $21.78(0.28)$ & $17.81(0.37)$ & $28.30(1.52)$ & $20.44(1.02)$ & $31.08(1.64)$ \\
Gas & $18.42(0.83)$ & $16.91(1.09)$ & $20.87(4.85)$ & $18.99(1.02)$ & $20.06(1.05)$
\end{tabular}

ethanol. Water soluble non-structural sugars and organic acids content was determined by high performance liquid chromatography (HPLC) after acid hydrolysis (using $72 \%$ sulfuric acid to make a $4 \%$ acid solution and autoclaving at $121^{\circ} \mathrm{C}$ for $1 \mathrm{~h}$ followed by filtering through a $0.25 \mu \mathrm{m}$ filter). Organic acids were analyzed on an Aminex HPX-87H column (BioRad Laboratories, Hercules, CA), with a column temperature of $55^{\circ} \mathrm{C}$, using a diode array detector, a mobile phase of $0.01 \mathrm{M}$ sulfuric acid, and a flow rate of $0.6 \mathrm{~mL} \mathrm{~min}-1$. After neutralization with calcium carbonate, sugars were analyzed on an Aminex HPX-87P column (BioRad Laboratories, Hercules, CA) with a column temperature of $85^{\circ} \mathrm{C}$ using a refractive index detector, a mobile phase of $18 \mathrm{M} \Omega$ ultrapure water,

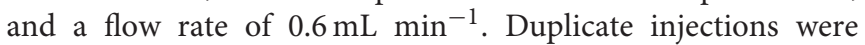
performed for all samples. Acid-soluble lignin was determined by measuring absorbance at $320 \mathrm{~nm}$ with an ultraviolet-visible spectrophotometer (Varian Cary 50, Agilent, Santa Clara, CA) and calculating the concentration using Beer's Law with an extinction coefficient of 30 . Protein was determined by measuring percent nitrogen using a LECO TruSpec CHN (St. Joseph, MI) and then multiplying that value by a nitrogen-protein conversion factor of 4.6.

\section{Thermochemical Conversion}

Microwave enhanced fast pyrolysis was used for thermochemical conversion and is described here in brief with further details found in Klinger et al. (2016). The experimental apparatus consists of a quartz tube surrounded by an insulated microwave cavity (furnace) that can be independently heated (up to $550^{\circ} \mathrm{C}$ ) on one end and is cooled with dry ice on the other end, while being purged with $\mathrm{N}_{2}$. A $3 \mathrm{~kW}$ SM1250D model microwave generator (MKS Instruments, Andover, MA) was used in combination with a waveguide and microwave autotuners to focus a microwave beam onto $3 \mathrm{~g}$ samples (comprised of three one gram pellets described above) inside the cavity to achieve fast pyrolysis heating rates. An infrared camera (A655sc with $25^{\circ}$ lens, FLIR) was used to monitor sample temperature during the reaction. In a typical experiment a region of interest at least $20 \times 15$ pixels $(325 \mu \mathrm{m}$ /pixel) was recorded to track the spatial and temporal temperature distribution. This spatial distribution varied by no more than $20-30^{\circ} \mathrm{C}$ during any given video frame. A virtual instrument developed in LabVIEW (National Instruments, Austin, TX) was used to control the microwave power applied to the sample. Product vapors and gases are swept through the dry ice cooled section of the quartz tube to a filter that recovers condensable vapors while permanent gasses are passed through a digital gas flow meter (FMA-4312, Omega Engineering) and gas analyzer (7905A, Nova Analytical Systems). Gas analysis uses thermal conductivity for $\mathrm{H}_{2}$, an electrochemical sensor for $\mathrm{O}_{2}$, and NDIR infrared detection for $\mathrm{CO}, \mathrm{CO}_{2}, \mathrm{CH}_{4}$, and total hydrocarbons (HC). Char is weighed after each reaction for a complete mass balance. Experiments were run in triplicate (or greater).

Bio-oil quality analysis was performed by ALS Environmental for carbon, hydrogen, nitrogen (CHN) using ASTM - D5291, for water by Karl Fischer using ASTM - E1064, and for acid number by ASTM - D3339. 


\section{Biochemical Conversion}

Dilute acid pretreatment was performed by accelerated solvent extraction using $1 \mathrm{wt} \%$ sulfuric acid at $160^{\circ} \mathrm{C}$. Enzymatic hydrolysis was conducted using a modified version of the procedure described in Selig et al. (2008). Pretreated solids were enzymatically hydrolyzed by adding $1.0 \mathrm{~g}$ of dry biomass (dried at $105^{\circ} \mathrm{C}$ ) to a $50 \mathrm{~mL}$ incubation flask with $5 \mathrm{~mL}$ of $0.1 \mathrm{M}$ citric acid buffer ( $\mathrm{pH} 4.8$ ), $100 \mu \mathrm{L}$ of $2 \%$ sodium azide solution, and the appropriate amount of nanopure water to reach a final reaction volume of $10 \mathrm{~mL}$. Enzymes were added at $20 \mathrm{mg} / \mathrm{g}$ dry biomass for Cellic ${ }^{\circledR}$ CTec2 (Novozymes, Franklin, NC, USA) and $2 \mathrm{mg} / \mathrm{g}$ biomass for Cellic ${ }^{\circledR}$ HTec2. The density of all solutions and biomass were assumed as $1 \mathrm{~g} / \mathrm{mL}$. Enzyme and substrate blanks were prepared as controls. To investigate sugar release kinetics $150 \mu \mathrm{L}$ aliquots of liquor were removed after $6,12,24,48,72$, and $120 \mathrm{~h}$ of incubation at $50^{\circ} \mathrm{C}$, filtered through a $0.2 \mu \mathrm{m}$ filter, and analyzed for monomeric sugars using HPLC (Agilent HPLC Model 1260; Agilent Technologies; Santa Clara, CA). Sugars were analyzed on an Aminex HPX-87P column (BioRad Laboratories; Hercules, CA) with a column temperature of $85^{\circ} \mathrm{C}$ using a refractive index detector, a mobile phase of $18 \mathrm{M} \Omega$ ultrapure water, and a flow rate of $0.6 \mathrm{~mL} / \mathrm{min}$. Duplicate injections were performed for each sample. Each feedstock was analyzed through dilute acid pretreatment and enzymatic hydrolysis in triplicate. The sugars evaluated for this study, defined as the "Theoretical Yield" included the sum of released glucose, xylose, galactose, arabinose, mannose, and cellobiose divided by those sugars present in the pretreated material multiplied by 100 .

\section{RESULTS AND DISCUSSION}

\section{Biochemical Conversion With Air Classification}

A partial suite of the compositional analysis for the whole tree, air classified, and hand fractionated clean chips for hybrid poplar and shrub willow can be seen in Table 2. From this data it is clear that fractionation of SRWC provides several benefits for biochemical conversion. In this data, the clean chips material is comprised of the hand separated fraction of white wood chips that represent the best possible feedstock for biochemical conversion due to low extractives and high sugar. Air classified material approaches clean chips in terms of lower ash, fewer extractives, and increased sugars content; however, even with the removal of leaves, the lower quality of the remaining bark content attached to twigs, branches, and chips is still evident in the composition. Decreasing ash can lead to more effective dilute acid pretreatment, because ash can neutralize the acid, and reducing extractives typically increases enzymatic activity. Air classification boosted the hybrid poplar total sugar content above $59 \%$, which is generally agreed upon as suitable for biochemical conversion (Davis et al., 2013). Additional compositional analysis data can be found in the supporting information for these same samples.

The effects of air classification and hand separation on enzymatic hydrolysis can be seen in Figure 1 with hybrid poplar in panel $\mathrm{A}$ and shrub willow in panel $\mathrm{B}$. The results presented here are for the theoretical yield, which is the amount of sugar released over the amount of sugar contained in the sample based on hydrolysis time. It is important to note that preprocessing steps like air classification can increase total sugar content, which means that hydrolyzing a gram of air classified material can ultimately release more sugar than hydrolyzing whole tree material, given the same theoretical yield. Unsurprisingly, for both materials the hand separated "clean" material gave the best conversion results with a yield of about $75 \%$ of the theoretical maximum for coppices. However, while clean chips of each coppice material gave similar maximum sugar yields the "whole" materials gave significantly different results; with hybrid poplar releasing $67 \%$ of the available sugars compared to $57 \%$ for the shrub willow. This drastic difference in sugar yields could be explained by the fact that the willow samples contained a greater amount of both ash and extractives, which inhibit pretreatment and hydrolysis, respectively. These results for hand separated coppice are in agreement with work performed by Dou et al. (2017b). It can also be seen that air classification improves enzymatic hydrolysis yield for both feedstocks. Improved results can be tied directly to decreased ash and extractives content in each of the samples (Table 2). Air classification removes basically all of the leafy material (and some of the bark in the case of hybrid poplar) which decreases the extractives content significantly. Error bars on the enzymatic hydrolysis data are significant ( $>5 \%$ ) on a few of the data points due to the runs being performed in triplicate. These small sample size error bars make a strict interpretation of the results difficult. When considering potential improvements achievable by using air classification it is useful to consider the average error of for a larger enzymatic hydrolysis sample size. The average error for EH results across all 36 of the samples (which were run in triplicate) was 3.7\%. If the sugar yield data is interpreted through a lens of $\sim 4 \%$ error it becomes clear that air classification makes a significant improvement. At $4 \%$ error air classified material is generally comparable to clean chips and better than whole tree material, especially for shrub willow.

\section{Thermochemical Conversion With Air Classification}

Initial pyrolysis experiments investigated the potential benefits of air classification on fast pyrolysis. Theoretically, air classification could remove ash species and improve liquid yields. However, it should be noted that the thermochemical specification of $<1 \%$ ash is not met (Jones et al., 2013) and more preprocessing would be required in order to upgrade SRWC to a conversion ready feedstocks. Results from the pyrolysis of whole tree hybrid poplar as well as hand separated material and both heavy and light air classified samples can be seen in Table 3. It can be seen that the whole hybrid poplar has a liquid yield of $59.81 \%$ while the clean chips and unclean mix yielded 65.28 and $50.84 \%$ liquid, respectively. The heavy fraction of material separated by air classification showed a significant decrease in ash based on compositional analysis (Table 2) but gave a liquid yield of $60.56 \%$ that was not statistically different than the whole tree sample. The light fraction of the air classified material had a liquid yield of $48.86 \%$ which was within error for the unclean mix sample. It 

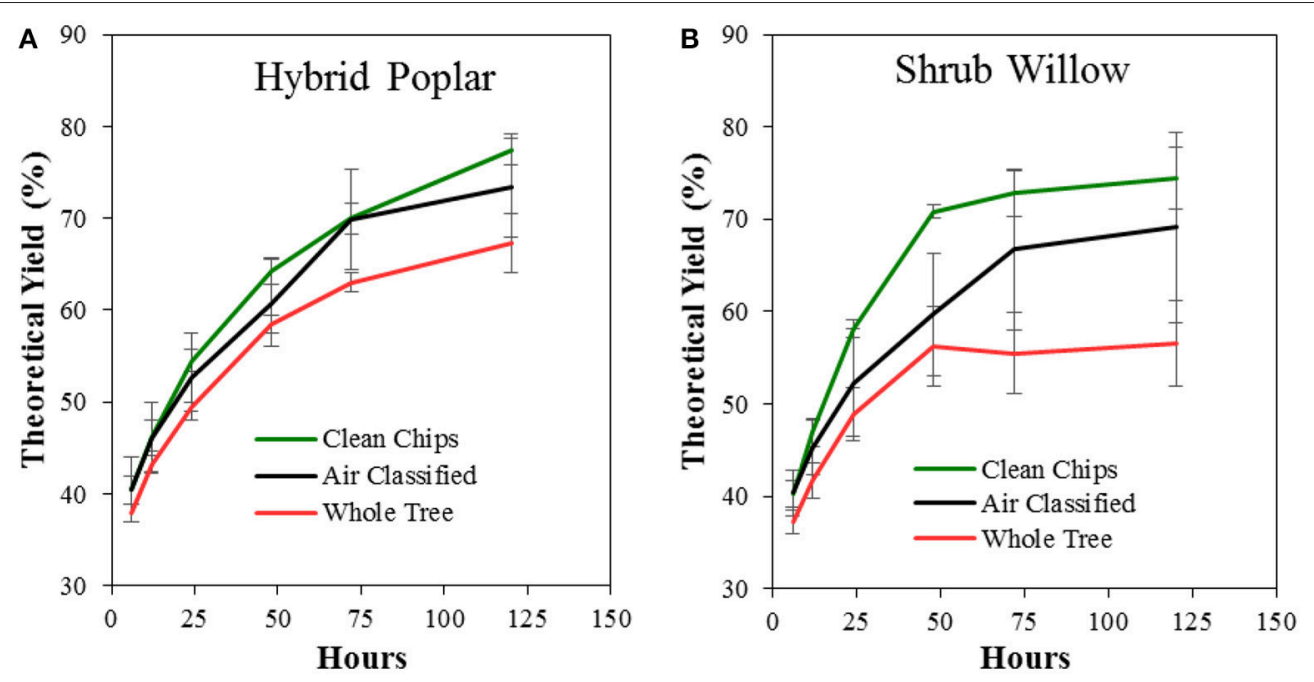

FIGURE 1 | Biochemical conversion of whole and fractionated (A) hybrid poplar and (B) shrub willow.

can also be seen in Table 3 that char and gas yields for the air classified material followed the same trends shown by the hand separated material. Overall, pyrolysis of air classified material showed the expected trends based on the composition but there was no significant benefit to air classification when the total liquid yields were weighted by the mass fraction of material in each bin (i.e., Table 1). Additional data on the effect of varying air classification fan speed on pyrolysis yield can be seen in the supporting information; however, the results mirror what is seen in the manuscript.

\section{Feedstock Preprocessing Combined With Hybrid Conversion}

Biochemical conversion exhibits a much greater sugar release after air classification preprocessing compared to the modest increase in pyrolytic liquid from thermochemical conversion of SRWCs. Additionally, the pyrolysis oil quality has potential to be improved when processing lignin rich leaf and bark residue separated by air classification and/or lignin rich residue from biochemical conversion.

Pyrolysis yields from the whole tree, hand separated clean chips and unclean mix, and biochemical conversion residue for both poplar and willow can be seen in Table 4. As expected, the clean chips had the highest liquid yields (of around 65\%) while the unclean mix (which contains everything that is not clean chipped material) had the lowest liquid yields (around $50 \%$ ). The whole tree material gave intermediate oil yields of 55$60 \%$ for the willow and poplar, respectively. These intermediate oil yields are expected to be close to the yields for the clean chips given that the bulk each material is made of heartwood instead of bark and leaves. Leftover lignin rich residue from the biochemical conversion process gave oil yields similar to that of the whole tree material. However, char yields for the lignin rich residue were significantly higher than the whole material. This is likely the case because lignin is largely responsible for char-forming reactions when compared to cellulose and hemicellulose (Evans et al., 1986; Sharma et al., 2004; Patwardhan et al., 2011). Interestingly, the biochemical conversion residues produced less char residuals than previous studies on lignin, possibly because of the removal of extractives and inorganics. In this sense, the biochemical pathway acts as a pretreatment stage for the thermochemical conversion. In addition, previous studies have noted that differential thermogravimetric curves of lignin from enzymatic hydrolysis look more like natural lignin than organosolv lignin and may reflect the relatively high yield compared to prior work (Cho et al., 2012).

Apart from simply maximizing pyrolysis liquid yields it is important to understand something about the quality of the bio-oil. However, there is still very little consensus on what constitutes a high quality bio-oil; to date, primary measurements of bio-oil quality have centered on reduced acidity, as measured by the total acid number (TAN), reducing water content, and reducing oxygen content. For this work bio-oil quality metrics can be seen in Table 5. The TAN is highest for clean chips and whole tree materials and decreases slightly for unclean (leaf and bark rich) material. The TAN can be seen to have decreased significantly for the biochemical conversion residue. This indicates that the quality of the bio-oil produced from these waste products has at least some of the key qualities for a higher value oil. It also appears that the majority of the nitrogen resides in the lignin rich fractions of the coppice but there is no clear trend related to water content or carbon content based on the Karl Fisher or CHN analysis, noting that the relative measures of carbon are likely skewed by measuring the whole water-laden liquids. If the water measurements are directly factored out, the qualitative results are largely unchanged. For hybrid poplar the lignin-rich residues produced the highest carbon content liquid followed by the clean chips, while the highest fractions in willow was clean chips followed by lignin-rich residues. Improved measurement methods of water content, and 
TABLE 4 | Liquid, char, and gas yields from various fractions of hybrid poplar and shrub willow.

\begin{tabular}{|c|c|c|c|c|c|c|c|c|}
\hline & \multicolumn{4}{|c|}{ Hybrid poplar } & \multicolumn{4}{|c|}{ Shrub willow } \\
\hline & $\begin{array}{c}\text { Whole } \\
\text { tree }\end{array}$ & $\begin{array}{l}\text { Clean } \\
\text { chips }\end{array}$ & $\begin{array}{l}\text { Unclean } \\
\text { mix }\end{array}$ & $\begin{array}{l}\text { Biochem } \\
\text { residue }\end{array}$ & $\begin{array}{c}\text { Whole } \\
\text { tree }\end{array}$ & $\begin{array}{l}\text { Clean } \\
\text { chips }\end{array}$ & $\begin{array}{l}\text { Unclean } \\
\text { mix }\end{array}$ & $\begin{array}{l}\text { Biochem } \\
\text { residue }\end{array}$ \\
\hline Liquid & $59.81(0.87)$ & $65.28(0.94)$ & 50.84 (3.39) & $57.69(2.25)$ & 54.30 (1.89) & 63.59 (1.55) & $51.65(1.81)$ & $53.54(2.16)$ \\
\hline Char & $21.78(0.28)$ & $17.81(0.37)$ & 28.30 (1.52) & $25.38(0.46)$ & $21.49(1.76)$ & $17.88(1.44)$ & 26.61 (1.19) & 26.95 (0.29) \\
\hline Gas & $18.42(0.83)$ & $16.91(1.09)$ & 20.87 (4.85) & 16.93 (1.96) & $24.21(2.21)$ & 18.53 (2.42) & $21.74(1.45)$ & $19.52(2.35)$ \\
\hline
\end{tabular}

Mean (standard deviation).

TABLE 5 | Bio-oil properties from fast pyrolysis conversion.

\begin{tabular}{|c|c|c|c|c|c|c|c|c|}
\hline & \multicolumn{4}{|c|}{ Hybrid poplar } & \multicolumn{4}{|c|}{ Shrub willow } \\
\hline & Whole & Clean chips & Unclean mix & Biochem residue & Whole & Clean chips & Unclean mix & Biochem residue \\
\hline C (wt\%) & 31.34 & 37.95 & 28.52 & 45.19 & 37.39 & 41.74 & 28.5 & 37.78 \\
\hline $\mathrm{H}$ (wt\%) & 8.56 & 7.97 & 9.11 & 8.1 & 8.3 & 7.28 & 8.72 & 8.53 \\
\hline O (wt\%) & 59.89 & 54.05 & 61.83 & 46.2 & 54.06 & 50.92 & 62.29 & 53.25 \\
\hline N (wt\%) & 0.21 & 0.03 & 0.54 & 0.51 & 0.25 & 0.06 & 0.49 & 0.44 \\
\hline Water by KF (wt\%) & 23.2 & 26 & 14.3 & 27.7 & 11.3 & 13.1 & 19.1 & 10.3 \\
\hline TAN mg KOH/g & 134 & 134 & 102 & 90 & 136 & 136 & 116 & 10 \\
\hline
\end{tabular}

accounting between bound feedstock moisture and chemically formed water through primary and secondary reactions, needs further future development.

It should be noted that the use of a combined bio/thermochemical process has the potential to increase the overall yield of valuable products. Simple biochemical conversion converts about $60 \%$ of the original mass to fermentable sugars while pyrolysis provides about $65 \%$ yield of liquid bio-oil products. By utilizing air classification as a preprocessing technique to remove material detrimental to biochemical conversion, followed by pyrolysis of the lignin rich biochemical residue (and air separated leaf/bark) in a hybrid conversion process, the combined yield of sugars and oil can be increased above $80 \%$ and significantly increase overall biomass utilization.

\section{CONCLUSION}

In conclusion, air classification is a simple preprocessing strategy that has the potential to improve sugars release during enzymatic hydrolysis by $6-12 \%$ for short rotation woody coppice. The total theoretical sugar release for these hardwood coppices was $\sim 70 \%$ which suggests that they could be utilized for biochemical conversion. Improved enzymatic hydrolysis yields after air classification can be tied to the compositional changes of reduced ash and extractives that can neutralize dilute acid pretreatment and inhibit fermentation. However, air classification has little to no effect on pyrolytic thermochemical conversion of coppice as it removes material without returning a significant improvement in oil yield. It was also shown that pyrolysis of biochemical conversion lignin rich residue gives liquid yields comparable to whole tree pyrolysis with a higher quality oil that has $\sim 60 \%$ reduced total acid number. Using this hybrid bio/thermochemical strategy can improve yields of fermentable sugars and oil to $\sim 80 \%$ instead of the $60 \%$ yield of sugars or oil when using a single conversion strategy. Overall, it has been shown that preprocessing and hybrid conversion pathways are a viable strategy for maximizing biorefinery viability.

\section{FUNDING}

The US Government retains and the publisher, by accepting the article for publication, acknowledges that the US Government retains a non-exclusive, paid-up, irrevocable, worldwide license to publish or reproduce the published form of this manuscript, or allow others to do so, for US Government purposes. The authors have no relevant affiliations, or financial involvement, with any organization or entity with a financial interest in, or financial conflict with, the subject matter or materials discussed in the manuscript. The views and opinions of the authors expressed herein do not necessarily state or reflect those of the United States Government or any agency thereof. Neither the United States Government nor any agency thereof, nor any of their employees, makes any warranty, expressed or implied, or assumes any legal liability or responsibility for the accuracy, completeness, or usefulness of any information, apparatus, product, or process disclosed, or represents that its use would not infringe privately owned rights.

\section{AUTHOR CONTRIBUTIONS}

CW: idea conception, data analysis, primary writer; RE: idea contribution, data analysis, authored sections; SH: idea analysis and experimental work; EF and BT for experimental work and editing. JK: Idea refinement and experimental work for the thermochemical conversion section and draft editing. 


\section{ACKNOWLEDGMENTS}

The authors would also like to thank Mark Eisenbies, Tim Volk, and Obste Therasme from the College of Environmental Science and Forestry, State University of New York and

\section{REFERENCES}

Al Afas, N., Marron, N., Zavalloni, C., and Ceulemans, R. (2008). Growth and production of a short-rotation coppice culture of poplar-IV: fine root characteristics of five poplar clones. Biomass Bioener. 32, 494-502. doi: 10.1016/j.biombioe.2007.11.007

Carpenter, D., Westover, T., Howe, D., Deutch, S., Starace, A., Emerson, R., et al. (2017). Catalytic hydroprocessing of fast pyrolysis oils: impact of biomass feedstock on process efficiency. Biomass Bioener. 96, 142-151. doi: 10.1016/j.biombioe.2016.09.012

Chang, C. C., Green, S. K., Williams, C. L., Dauenhauer, P. J., and Fan, W. (2014). Ultra-selective cycloaddition of dimethylfuran for renewable p-xylene with H-BEA. Green Chem. 16, 585-588. doi: 10.1039/C3GC40740C

Cho, J., Chu, S., Dauenhauer, P. J., and Huber, G. W. (2012). Kinetics and reaction chemistry for slow pyrolysis of enzymatic hydrolysis lignin and organosolv extracted lignin derived from maplewood. Green Chem. 14, 428-439. doi: 10.1039/C1GC16222E

Davis, R., Tao, L., Tan, E., Biddy, M., Beckham, G., Scarlata, C., et al. (2013). Process Design and Economics for the Conversion of Lignocellulosic Biomass to Hydrocarbons: Dilute-Acid And Enzymatic Deconstruction of Biomass to Sugars and Biological Conversion of Sugars to Hydrocarbons. Golden, CO: National Renewable Energy Laboratory (NREL).

De Wild, P. J., Huijgen, W. J. J., and Gosselink, R. J. A. (2014). Lignin pyrolysis for profitable lignocellulosic biorefineries. Biofuels Bioprod. Bioref. 8, 645-657. doi: 10.1002/bbb. 1474

Dou, C., Chandler, D. S., Resende, F. L. P., and Bura, R. (2017a). Fast pyrolysis of short rotation coppice poplar: an investigation in thermochemical conversion of a realistic feedstock for the biorefinery. ACS Sus. Chem. Eng. 5, 6746-6755. doi: 10.1021/acssuschemeng.7b01000

Dou, C., Marcondes, W. F., Djaja, J. E., Bura, R., and Gustafson, R. (2017b). Can we use short rotation coppice poplar for sugar based biorefinery feedstock? Bioconversion of 2-year-old poplar grown as short rotation coppice. Biotechnol. Biofuels 10:144. doi: 10.1186/s13068-017-0829-6

Evans, R. J., Milne, T. A., and Soltys, M. N. (1986). Direct mass-spectrometric studies of the pyrolysis of carbonaceous fuels: III. Primary pyrolysis of lignin. J. Anal. Appl. Pyroly. 9, 207-236. doi: 10.1016/0165-2370(86)80012-2

Green, S. K., Patet, R. E., Nikbin, N., Williams, C. L., Chang, C. C., Yu, J., et al. (2016). Diels-Alder cycloaddition of 2-methylfuran and ethylene for renewable toluene. Appl. Catal. B Environ. 180, 487-496. doi: 10.1016/j.apcatb.2015.06.044

Jones, S., Meyer, P., Snowden-Swan, L., Padmaperuma, A., Tan, E., Dutta, A., et al. (2013). Process Design and Economics for the Conversion of Lignocellulosic Biomass to Hydrocarbon Fuels: Fast Pyrolysis and Hydrotreating Bio-Oil Pathway. Golden, CO: National Renewable Energy Laboratory (NREL).

Kauter, D., Lewandowski, I., and Claupein, W. (2003). Quantity and quality of harvestable biomass from Populus short rotation coppice for solid fuel use-a review of the physiological basis and management influences. Biomass Bioener. 24, 411-427. doi: 10.1016/S0961-9534(02)00177-0

Klinger, J., Bar-Ziv, E., Shonnard, D., Westover, T., and Emerson, R. (2016). Predicting properties of gas and solid streams by intrinsic kinetics of fast pyrolysis of wood. Energy Fuels 30, 318-325. doi: 10.1021/acs.energyfuels.5b01877

Mitchell, C. P. (1992). Ecophysiology of short rotation forest crops. Biomass Bioener. 2, 25-37. doi: 10.1016/0961-9534(92)90085-5

Nigam, P. S., and Singh, A. (2011). Production of liquid biofuels from renewable resources. Prod. Energy Combust. Sci. 37, 52-68. doi: 10.1016/j.pecs.2010.01.003

Njakou Djomo, S., Ac, A., Zenone, T., De Groote, T., Bergante, S., Facciotto, G., et al. (2015). Energy performances of intensive and extensive short rotation
Brian Stanton and Rich Shuren from Greenwood Resources for providing materials. This research was supported by the US Department of Energy under Department of Energy Idaho Operations Office Contract No. DE-AC0705 ID 14517.

cropping systems for woody biomass production in the EU. Renew. Sust. Energy Rev. 41, 845-854. doi: 10.1016/j.rser.2014.08.058

Patwardhan, P. R., Brown, R. C., and Shanks, B. H. (2011). Understanding the fast pyrolysis of lignin. ChemSusChem 4, 1629-1636. doi: 10.1002/cssc.201100133

Ragauskas, A. J., Beckham, G. T., Biddy, M. J., Chandra, R., Chen, F., Davis, M. F., et al. (2014). Lignin valorization: improving lignin processing in the biorefinery. Science 344:1246843. doi: 10.1126/science.1246843

Sannigrahi, P., Ragauskas, A. J., and Tuskan, G. A. (2010). Poplar as a feedstock for biofuels: a review of compositional characteristics. Biofuels Bioprod. Bioref. 4, 209-226. doi: 10.1002/bbb.206

Selig, M., Weiss, N., and Ji, Y. (2008). Enzymatic Saccharification of Lignocellulosic Biomass: Laboratory Analytical Procedure (LAP). Golden, CO: National Renewable Energy Laboratory.

Sharma, R. K., Wooten, J. B., Baliga, V. L., Lin, X., Geoffrey Chan, W., and Hajaligol, M. R. (2004). Characterization of chars from pyrolysis of lignin. Fuel 83, 1469-1482. doi: 10.1016/j.fuel.2003.11.015

Sluiter, J. B., Ruiz, R. O., Scarlata, C. J., Sluiter, A. D., and Templeton, D. W. (2010). Compositional analysis of lignocellulosic feedstocks. 1. Review and description of methods. J. Agric. Food Chem. 58, 9043-9053. doi: 10.1021/jf1008023

US Department of Energy (2011). U.S. Billion-Ton Update: Biomass Supply for a Bioenergy and Bioproducts Industry, eds R. D. Perlack and B. J. Stokes. ORNL/TM-2011/224. Oak Ridge, TN: Oak Ridge National Laboratory.

Volk, T., Abrahamson, L., Nowak, C., Smart, L., Tharakan, P., and White, E. (2006). The development of short-rotation willow in the northeastern United States for bioenergy and bioproducts, agroforestry and phytoremediation. Biomass Bioener. 30, 715-727. doi: 10.1016/j.biombioe.2006. 03.001

Williams, C. L., Chang, C.C., Do, P., Nikbin, N., Caratzoulas, S., Vlachos, D. G., et al. (2012). Cycloaddition of biomass-derived furans for catalytic production of renewablep-xylene. ACS Catal. 2, 935-939. doi: 10.1021/cs300011a

Williams, C. L., Emerson, R. M., and Tumuluru, J. S. (2017). "Biomass compositional analysis for conversion to renewable fuels and chemicals," in Biomass Volume Estimation and Valorization for Energy, ed J. S. Tumuluru (Rijeka: InTech), 251-270.

Williams, C. L., Westover, T. L., Emerson, R. M., Tumuluru, J. S., and Li, C. (2016). Sources of biomass feedstock variability and the potential impact on biofuels production. Bioener. Res. 9, 1-14. doi: 10.1007/s12155-015-9694-y

Wyman, C. E., Dale, B. E., Elander, R. T., Holtzapple, M., Ladisch, M. R., Lee, Y. Y., et al. (2009). Comparative sugar recovery and fermentation data following pretreatment of poplar wood by leading technologies. Biotechnol. Prog. 25, 333-339. doi: 10.1002/btpr.142

Zinchik, S., Klinger, J. L., Westover, T. L., Donepudi, Y., Hernandez, S., Naber, J. D., et al. (2018). Evaluation of fast pyrolysis feedstock conversion with a mixing paddle reactor. Fuel Process. Technol. 171, 124-132. doi: 10.1016/j.fuproc.2017.11.012

Conflict of Interest Statement: The authors declare that the research was conducted in the absence of any commercial or financial relationships that could be construed as a potential conflict of interest.

Copyright (c) 2018 Williams, Emerson, Hernandez, Klinger, Fillerup and Thomas. This is an open-access article distributed under the terms of the Creative Commons Attribution License (CC BY). The use, distribution or reproduction in other forums is permitted, provided the original author(s) and the copyright owner(s) are credited and that the original publication in this journal is cited, in accordance with accepted academic practice. No use, distribution or reproduction is permitted which does not comply with these terms. 